\title{
EFFECTIVENESS OF LEAF EXTRACT REDUCE INFLAMMATION REACTION IN HYPERCHOLESTEROLEMIA RATS
}

\author{
Puguh Santoso ${ }^{1}$, Ni Nyoman Wahyu Udayani ${ }^{1}$, I Nyoman Gede Tri Sutrisna ${ }^{1}$, Ketut Agus Adrianta ${ }^{1}$ \\ ${ }^{1}$ Akademi Farmasi Saraswati Denpasar (farmazi.sp@gmail.com)
}

\begin{abstract}
High blood cholesterol is often called hypercholesterolemia is a risk factor for the emergence of pathological conditions such as heart and blood vessel disease. Hypercholesterolemia has an important role in the occurrence of damage to the endothelial cells is mainly caused by oxidized LDL. Oxidation of LDL triggers the formation of TNF - $\alpha$.

Leaves messengers that allegedly contains flavonoids can improve the situation of hypercholesterolemia through the barriers specifically the expression of TNF - $\alpha$ increased due to hypercholesterolemia. Plants messengers known to contain alkaloids, flavonoids, tannins, saponins, polyphenols, calcium oxalate, fats, and essential oil. Flavonoids which has the ability to bind the atom to form free radicals not to excess free radicals, thereby inhibiting the oxidative modification of LDL become ox-LDL so it will not be formed atherosclerosis.

This study uses the Randomize pattern Pre and Post Test Control Group Design, using white rats (Rattusnovergicus) with Wistar strain aged 3-4 months, weighing 175-200 grams. Divided into four groups: Group I as a control with placebo, Group II treatment using extracts of ethanol leaves a messenger at a concentration of 10\%, Group III treatments using extracts of ethanol leaves a messenger at a concentration of $20 \%$, Group IV is to use the extract ethanol leaves errand at a concentration of $30 \%$.

It can be concluded at 4 dose group 30\% messengers leaf extract significantly different, $p<0.05$, so it can be said that the provision of effective messengers extract at a dose of $30 \%$.
\end{abstract}

Keywords: ethanol extract, hypercholesterolemia, inflammation, TNF - $\alpha$

\section{INTRODUCTION}

Coronary heart disease is the main manifestation of atherosclerosis, in which this process can occur at young age due to high-fat diet, so there is a narrowing and blockage of blood vessels coroner. Hypercholesterolemia can cause increased levels of TNF- $\alpha$ and IL-6 in patients with obesity. Reference [1] described the obese happen a macrophage infiltration in the white adipocyte tissue, which is the main source of production for proinflammatory cytokines. Past research has shown a relationship between high serum lipid levels with the incidence of atherosclerotic disease trigger coronary heart disease [2].

Some studies also indicate that chronic inflammation of the wall of the aorta due to fat accumulation caused by the oxidation of LDL cholesterol which can cause broken plaque and ended in the formation of thrombosis [3]. Hypercholesterolemia could initiate atherosclerosis which is the result of a multifactorial disorder was associated with cytokine proinflammatory, IF- $\gamma$ (Interferron- $\gamma$ ), IL $-1 \beta$ (interleukin-1 $\beta$ ), IL-6 (interleukin-6) and TNF- $\alpha$, but did not provide significant change to an increase in IL - $1 \beta$ [4]. Tumor necrosis factor-alpha (TNF- $\alpha$ ) is one of the potent pro-inflammatory cytokines. Sitokin known to play a pathogenic role in chronic inflammatory disease. TNF- $\alpha$ is produced excess in adipocyte tissue in mouse models of obesity and plays an important role in the formation of atherosclerosis.

Peperomiapellucida L. is a weed plant that normally grows wild in damp places and crowded.This plant known to contain alkaloids, flavonoids, tannins, saponins, polyphenols, calcium oxalate, fat, and essential oils.

A research by Gianello et al. (2009) said that the planthas anticancer activity and it is also capable of capturing free radicals that can be used as natural source of antioxidants. It can be consumed as fresh vegetables and can be consumed daily.

Empirically, this plant has been used in the treatment of fever, abdominal disease, or other external treatment. It is also efficacious for pain in rheumatoid arthritis, gout, headache, abdominal pain, abscesses, boils, acne, skin 
inflammation, wound bruises and minor burns. The plant leaves can also be used as an antipyretic. Saponins contained in the leaves specifically used to lower serum cholesterol activity, which resulted by reducing the enterohepatic circulation of bile acids by inhibiting the oxidation of LDL cholesterol. The existence of barriers LDL oxidation reaction will be to lower cholesterol levels in the blood [5].

Flavonoids in the leaves is capable to reduce intracellular ROS by binding with the free radicals then the bonds will be able to stabilize peroxy makes synergy activation will be reduced, the result would inhibit the oxidation of LDL cholesterol. These obstacles will be able to reduce LDL oxidation, where a decrease in LDL oxidation would inhibit the activation of NF-kB, resulting in reduced levels of TNF$\alpha$ in the circulation. NF-kB is a transcription factor cells that can control the expression of several genes including TNF- $\alpha$ and IL-1 [6]. Flavonoid also acts as a compound that can reduce triglyceride (TGA) and increase HDL.Flavonoid is also said to be able to raise the density of LDL receptors in the liver and binds apolipoprotein B. In addition, according to a study conducted by Casaschi et al. (2004) said that flavonoids work to lower cholesterol from the blood by blocking the action of the enzyme 3-hydroxy 3methylglutaryl coenzyme A reductase (HMG Co-A reductase inhibitors) [7], [8].

\section{METHODS AND PROCEDURE}

This research is an experimental study with pre-posttest design controlgroup using wistar strain rats were obtained from the Laboratory of Veterinary Faculty at Udayana University.

The research material used is Peperomiapellucida leafs, which is extracted with $96 \%$ ethanol. The leafs obtained around Denpasar and determined at the Indonesian Institute of Sciences, Bedugul, Bali. Another material used is high cholesterol food and animal experiments: mice with the inclusion criteria (Wistar strain female rats are healthy / actively moves, age 2-3 months, weight 200-250 g) and the exclusion criteria (mice looked sick: motion inactive, do not want to eat, a fight between rats and mice die before getting treatment).

\section{A. Production of $96 \%$ ethanol extract of the leafs}

Leaves that already cleaned then dried using an oven at a temperature $40^{\circ} \mathrm{C}$. The dried leafs then crushed using a blender. That dry powder then weighed 1,500 grams and gradually macerated using ethanol $96 \%$ as much as $525 \mathrm{ml}$, put in jar, tightly closed and protected from light. Remaceration done 2 times to get the result. Results filtrate in the form of aqueous extract was evaporated with a rotary evaporator at a temperature of $40^{\circ} \mathrm{Cand}$ eventually obtained extract thick.

\section{B. Making dose of ethanol extract of 10\%, 20\% and 30 .}

Dose $10 \%$ weigh $10 \mathrm{~g}$ extract in aqua add up to $100 \mathrm{ml}$, $20 \%$ dose of extract weighed $20 \mathrm{~g}$ was added to $100 \mathrm{ml}$ aqua, a dose of $30 \%$ weighed aqua extract was added to 100 $\mathrm{ml}$.

\section{Treatment of experimental animals}

A total of 28 rats were divided into 4 groups adapted for a week.

\section{Testing phase}

Research procedure as follows:

1. 28 rats were fed high-fat feed for 30 days and then check cholesterol levels through chantus medial orbital sinus as a pre-test.

2. Rats are grouped into 4 groups, each group consisted of 7 mice. The group consists of the normal control group / comparison, and the treatment group were given a dose of $10 \%, 20 \%$ and $30 \%$ ethanol extract of leaves per day.

3. Each group was treated as follows:

a. One as the normal control group was given only the standard high feed and drinking water ad libitum.

b. Group 2 was given the ethanol extract of the leaves messenger concentrations of $10 \%$ and highcholesterol foods orally for 30 days.

c. Group 3 was given ethanol extract of leafs concentration of $20 \%$ and high-cholesterol foods orally for 30 days.

d. Group 4 was given the ethanol extract of the leafs concentration of $20 \%$ and high-cholesterol foods orally for 30 days.

e. On $31^{\text {st }}$ day, $1 \mathrm{ml}$ of blood is taken through the medial orbital sinus chantus for checking levels of TNF- $\alpha$.

4. Blood of mice then centrifuged at a speed of $4000 \mathrm{rpm}$ for 5 minutes to obtain serum

\section{The level of $T N F-\alpha$}

A total of $0.5 \mathrm{ml}$ of serum was brought and examined its levels of TNF- $\alpha$ in the laboratory Mantra Medika Denpasar. Levels of TNF- $\alpha$ is read at a temperature of $37^{\circ} \mathrm{C}$ and expressed in $\mathrm{mg} / \mathrm{L}$.

\section{RESULTS AND DISCUSSION}

In this experiment the animal is given atherogenic diet for 60 days, in Table 1 shows hypercholesterolemia in all groups. On the condition of hypercholesterolemia lead to an increase LDL in the blood rises, free radicals unite modification of LDL into Ox-LDL. Ox-LDL is the one that will beendocytosis by macrophages via the scavenger receptor (Rc-S), it will form a foam cell and further would be fatty streak [9]. Macrophages trigger the forming of TNF- $\alpha$, TNF- $\alpha$ triggers inflammation and stimulate the infiltration of mononuclear cells in the walls of arteries resulting in enlargement of the plaque and fibrous cap is formed is referred to as atheroscleroticplaque.Forming of that plaque causes narrowing of the lumen of the artery, which resulting reduced blood flow. When the atherosclerotic plaque rupture and thrombosis, in which it blocked a coronary artery, it will be causing coronary heart disease appears [11]. 
Table 1.

Measurement of Blood Serum Levels of TNF- $\alpha$

\begin{tabular}{|c|c|c|c|}
\hline \multirow[t]{2}{*}{ No } & \multirow[t]{2}{*}{ Group } & \multicolumn{2}{|c|}{ TNF- $\alpha$} \\
\hline & & Pre & Post \\
\hline 1 & \multirow{7}{*}{ Normal control } & 68,24 & 75,29 \\
\hline 2 & & 36,89 & 72,47 \\
\hline 3 & & 65,88 & 59,29 \\
\hline 4 & & 59,76 & 5129 \\
\hline 5 & & 51,26 & 52,24 \\
\hline 6 & & 51,76 & 75,76 \\
\hline 7 & & 51,56 & 52,45 \\
\hline 8 & \multirow{7}{*}{$\begin{array}{l}\text { Dose } 10 \% \text { extract }+ \\
\text { high cholesterol feed } \\
\text { P.O for } 30 \text { days }\end{array}$} & 57,41 & 72,47 \\
\hline 9 & & 67,29 & 70,59 \\
\hline 10 & & 68,24 & 60,71 \\
\hline 11 & & 46,59 & 66,82 \\
\hline 12 & & 64,47 & 66,82 \\
\hline 13 & & 76,71 & 77,65 \\
\hline 14 & & 48,00 & 58,82 \\
\hline 15 & \multirow{6}{*}{$\begin{array}{l}\text { Dose } 20 \% \text { extract }+ \\
\text { high cholesterol feed } \\
\text { P.O for } 30 \text { days }\end{array}$} & 59,76 & 85,05 \\
\hline 16 & & 56,47 & 167,03 \\
\hline 17 & & 64,47 & 58,82 \\
\hline 18 & & 60,24 & 150,63 \\
\hline 19 & & 124,68 & 91,53 \\
\hline 20 & & 85,77 & 72,00 \\
\hline 21 & & 77,18 & 60,71 \\
\hline 22 & \multirow{7}{*}{$\begin{array}{l}\text { Dose } 30 \% \text { extract }+ \\
\text { high cholesterol feed } \\
\text { P.O for } 30 \text { days }\end{array}$} & 85,05 & 47,53 \\
\hline 23 & & 79,06 & 68,71 \\
\hline 24 & & 60,71 & 71,06 \\
\hline 25 & & 68,35 & 53,65 \\
\hline 26 & & 64,94 & 46,59 \\
\hline 27 & & 77,65 & 35,34 \\
\hline 28 & & 80,72 & 59,76 \\
\hline
\end{tabular}

TNF- $\alpha$ is a proinflammatory cytokines in atherosclerosis which have pleiotropic properties [9]. TNF- $\alpha$ induce inflammation, smooth muscle cell proliferation and increase the adhesion of leukocytes to endothelial cells by inducing adhesion molecule [11].

A study showed that TNF- $\alpha$ effect on endothelial damage, causing changes in cell structure and cell structure abnormalities endotel. TNF- $\alpha$ improves the adhesion of leukocytes such as ICAM and V-CAM to the endothelial cells and triggers the accumulation of monocytes in atherosclerotic lesions that cause enlargement of the plaque and formed fibrous cap [13]. Atherogenic led to an increase in free radicals induced by LDL, the formation of free radical mediated oxidative modification of LDL become ox-LDL, oxidized LDL will cause endothelial dysfunction [15]. Ox-LDL would inhibit signal transduction for eNOS activity (endothelium Nitric Oxide Synthase) resulting in decreased NO production. The decrease of NO production will decrease vasodilation function of endothelial cells causing endothelial dysfunction. Endothelial dysfunction will stimulate an increase in NF-k $\beta$ which then increase the production of pro-inflammatory cytokines TNF- $\alpha$ one [14]. TNF- $\alpha$ causes inflammation by activating other proinflammatory factors. TNF- $\alpha$ plays a role in the destruction of endothelial cells by activation of several adhesion molecules [15].

In Table 1, the treatment group 10\% and 20\% shows no significant changes in levels of $\mathrm{TN}-\alpha$ so that it can be said that the first treatment with a dose of $10 \%$ and $20 \%$ were not able to reduce levels of $\mathrm{TN}-\alpha$. $\mathrm{P}>0.05$ between pre and post-test. The concentration of saponins flavonoid content has not been able to reduce levels of $\mathrm{TN}-\alpha$. In group 4 treated with a dose of $30 \%$ there is a change in levels of TNF alpha were significant so that it can be said that the treatment with a dose of $30 \%$ could reduce levels of TNF alpha were significantly, $\mathrm{P}<0.05$ was between pre and posttest.

In group 4 dose $30 \%$, the main bioactive component capability phenol which is a flavonoid that has the ability to bind the atom to form free radicals to no excess free radicals, by donating free electrons, thereby inhibiting the oxidative modification of LDL become ox-LDL so it would not form atherosclerotic [14]. Flavovonoid and saponins also have the ability as an analgesic anti-inflammatory. Mechanism of extracting Peperomiapellucida as an antiinflammatory can lead to lower the levels of TNF- $\alpha$ is through barriers against Nuclear Factor Kappa B (NF-кB). NF- $\kappa \mathrm{B}$ becomes activated because of the stimulus of ROS agents that cause endothelial dysfunction, pathogen exposure, DNA damage and physical stress. NF- $\mathrm{KB}$ function in controlling the expression of genes that encode pro-inflammatory cytokines and chemokines such as TNF$\alpha$, IL-1 $\beta$, IL-6 and other protein [16].

\section{CONCLUSION}

The result showed that group 4 with $30 \%$ dose of Peperomiapellucida L.extract is significantly different, $p$ $<0.05$, so it can be said that the extract is effective in a dose of $30 \%$.

\section{REFERENCES}

[1] Bastard.,Maachi, M., Lagathu, C., Kim, M.J., Caron, M., Vidal, H., Capeau, J., Feve, B. 2006. Recent advances in the relationship between obesity, inflammation, and insulin resistance. Eur. Cytokine Netw., Vol. 17 No 1, March 2006, 4-12.

[2] Twickler, TB., Cramer M. J. M., Dallinga-Thie, G. M., Chapman, M.J., Golberg, A. C. 2008. Dyslipidemia : Lipid Disorder. The Merck Manuals Medical Library. Available from http://www.merkmanuals.com/profesional/sec13/ch170/ch170b.html. (Accessed: 2013, April 03)

[3] Ahmed, E. 2001."Immune mechanisms in atherosclerosis". (dissertation). Konferensrummet, Centrum for MolekylärMedicin, KarolinskaSjukhuset. Available from :http://diss.kib.ki.se/2001/91628-4612-4/.(Accessed: 2013, April 01).

[4] Adeneye, A.A., Olaguniu, J.A. 2009. Preliminary hypoglycemic and hypolipidemicactivies of the aqueous seed extract of Carica papaya Linn.in Wistar rats.Jurnal Biology and Medicine Volume 1(1): 1 -10.

[5] Sargowo, D., Senorita, A., Widodo, A., 2010. Peranan ekstrak kulit manggis dalam penurunan kadar TNF- $\alpha$ dan IL-1 pada dyslipidemia. Malang: Universitas Brawijaya 
[6] Casaschi, A., Maiyoh, G. K., Rubio, B. K., Li, R.W., Adeli, K., and Theriault, A. G. 2004. The chalconexanthohumol inhibits triglyceride and apolipoprotein B secretion in HepG2 cells. Journal of Nutr.134: 1340-1346.

[7] Sekhon, S. 2012. Antioxidant, Anti-inflammatory and Hypolipidemic Properties of Apple Flavonols.Nova Scotia Agricultural College Truro; Nova Scotia

[8] Roos, R. 1999. Mechanisms of Disease: Atherosclerosis- An Inflammatory Disease. Nengi Journal Med, 1 : 115-126.

[9] Tanuwijaya, S. 2003. Recent Development in Pathogenesis of Atherosclerosis, in Atherosclerosis from Theory to Clinical Practice. Semarang Cardiology- Update (Mini 12 Cardiology - Update III). UniversitasDiponegoro., Semarang.

[10] Kleemann, R., Verschuren, L., Van, MJ., Nikolsky, Y and Cnubben, NH. (2007) Atherosclerosis and Liver Inflammation Induced by Increased Dietary Cholesterol Intake: a Combined Transcriptomics and Metabolomics Analysis. Genome Biomolecular8 : 200.

[11] Hansson, G.K., 2005. Inflammation, Atherosclerosis, and Coronary Artery Disease.The new england journal of medicine, 352:1685-95.
Available from : URL:http:/www.nejm.org. (Accessed: 2013, Maret 27).

[12] Bobik, A. and Kalinina, N. 2001. Tumor Necrosis Factor Receptor and Ligand Superfamily Family Members TNFRSF14 and LIGHT: New Players in Human Atherogenesis. Arterisclerosis, Thrombosis, and Vascular Biology, Journal of The American Heart Association, 24 (11): 2137- 2142.

[13] Esposito, K and Giugliano, D. 2006. Diet and Inflammation: A Link to Metabolic and Cardiovascular Disease. European Heart Journal, 27 (1): $15-20$

[14] Berg, A and Scherer, P. 2005. Adipose Tissue, Inflamation, and Cardiovascular Disease.Journal of American Heart Asociation, 21 (12) : 1873-1879.

[15] Duthie, G., Duthie, S and Kyle, J. 2000. Plant Polyphenols in Cancer as Nutritional Antioxidants. Nutrition Research Reviews. 79- 106.

[16] Nieman, D. 2007. Quercetin's Influence on Exercise-Induced Changes in Plasma Cytokines and Muscle and Leukocyte 